\title{
Effect of Salinity on the Growth Performance, Body Composition, Antioxidant Indexes of Perinereis aibuhitensis and Total Nitrogen in the Substrate
}

\author{
Fu Lv*, Qing Nie, Yebing Yu, Fei Liu, Linlan Lv, Weihong Zhao \\ College of Marine and Bioengineering, Jiangsu Key Laboratory of Biochemistry and Biotechnology of Marine Wetland \\ and Key Laboratory for Aquaculture and Ecology of Coastal Pool of Jiangsu Province, Yancheng Institute of \\ Technology, Yancheng, China \\ Email: *lvfuycit@163.com
}

How to cite this paper: Lv, F., Nie, Q., Yu, Y.B., Liu, F., Lv, L.L. and Zhao, W.H. (2017) Effect of Salinity on the Growth Performance, Body Composition, Antioxidant Indexes of Perinereis aibuhitensis and Total Nitrogen in the Substrate. Agricultural Sciences, 8, 1239-1252.

https://doi.org/10.4236/as.2017.811089

Received: September 29, 2017

Accepted: November 7, 2017

Published: November 10, 2017

Copyright $\odot 2017$ by authors and Scientific Research Publishing Inc. This work is licensed under the Creative Commons Attribution International License (CC BY 4.0).

http://creativecommons.org/licenses/by/4.0/

\begin{abstract}
In this study, the effects of different salinity levels $(9,12,15,18,21,24,27,30$, and 33) on the growth performance, body composition, antioxidant indexes of Perinereis aibuhitensis (initial average mass, $20.4 \pm 0.3 \mathrm{mg}$ ) and total nitrogen in the substrate were investigated. The survival rate, specific growth rate, feed coefficient, and protein efficiency ratio under different salinity levels were measured. The results showed that the survival rate of $P$. aibuhitensis at the salinity level of 9 was significantly lower than that of $P$. aibuhitensis at other salinity levels $(P<0.05)$. However, the survival rate of $P$. aibuhitensis at other salinity levels was not significant $(P>0.05)$. On the basis of quadratic polynomial fitting of the relationship between salinity levels and the specific growth rate, feed coefficient, and protein efficiency ratio, it was concluded that $25.36-25.9$ is the most suitable salinity range for the growth performance of $P$. aibuhitensis. The main body composition (moisture, crude fat, crude protein, and ash content) was measured at different salinity levels. The results indicated that, with the increase in salinity, the moisture content of $P$. aibuhitensis decreased gradually; in contrast, the ash content increased gradually, as the salinity level increased. However, in the salinity range of 18 to 33 , the difference in ash content was not significant $(P>0.05)$. Salinity had a significant influence on the crude protein content $(P<0.05)$, while it had no significant influence on crude body fat. Crude protein showed an increasing trend with the salinity increasing from 9 to 24 , and decreased with the salinity increasing from 24 to 33. Antioxidant indexes such as superoxide dismutase, catalase, glutathione, and malondialdehyde (MDA) were analyzed, showing that in vi-
\end{abstract}


vo MDA content was as low as the antioxidant activity at the salinity level of 24; this means low in vivo contents of active oxygen free radicals and excellent growth performance. This conclusion is consistent with that for other growth indexes. The total nitrogen content of the substrate in which the $P$. aibuhitensis specimens were cultured for 60 days was higher than the total nitrogen in the soil. With an increase in salinity, the total nitrogen content first decreased and then increased, and the lowest value was observed at the salinity level of about 24 .

\section{Keywords}

Perinereis aibuhitensis, Growth Performance, Body Composition, Antioxidant, Total Nitrogen Content, Substrate

\section{Introduction}

Salinity is a non-nutritional factor necessary for the survival and growth of aquatic organisms, and it has an impact on various physiological activities such as growth and metabolism [1]. The food intake of aquatic organisms varies on the basis of salinity. Salinity affects the digestion and absorption of food by changing the activity of the digestive enzymes, thus affecting the weight gain rate and specific growth rate of aquatic organisms. Therefore, it is particularly important to choose the most suitable salinity range for the survival and growth of aquatic organisms [2]. Body composition of aquatic organisms is composed of water, carbohydrates, proteins, fat, ash, etc. Previous studies have reported no significant differences in the effects of salinity on the body composition of fishes such as Paralichthys olivaceus [3] and Platichthys stellatus [4]. However, other studies have indicated that appropriate salinity levels helped to save the osmotic pressure energy in fish, resulting in good growth performance and high protein and fat content [5]. Superoxide dismutase (SOD), catalase (CAT), and other antioxidant enzymes are important constituents of the antioxidant enzyme system in an organism. A previous study on Sebastes schlegeli [6] showed that the activities of SOD and CAT in the blood increase gradually with the decrease trend; however, another study on the Nibea japonica [7] indicated that the activities of SOD and CAT in the liver, kidney, and muscle at different salinities showed no significant differences $(P>0.05)$, which may be related to the different salinity adaptations of different organisms.

$P$. aibuhitensis belongs to the family Nereididae and is mainly distributed in China; it is the main representative and dominant species or ecotype among intertidal polychaetes [8]. It has important applications in aquaculture [9] [10], fishing [11], and medical care [12], so the demand for $P$. aibuhitensis is high worldwide. However, the natural resources of $P$. aibuhitensis are depleting because of excessive harvesting and environmental degradation, so it has become 
difficult to meet the market demand. With breakthroughs in seed breeding and farming techniques, $P$. aibuhitensis has quickly become an important economic species for marine aquaculture in China's coastal areas. Impoundment pond farming was initially used to culture $P$. aibuhitensis. Recently, saturated wet soil technology was developed because it is highly efficient and environmentally friendly. P. aibuhitensis is a euryhaline animal that tolerates salinity levels from 5 to 45 [13]. Li et al. [14] analyzed the influence of salinity and body weight on the growth of $P$. aibuhitensis under impounded conditions; however, there are no reports under saturated moist soil conditions. In this study, the effects of salinity on the growth performance, body composition, antioxidant indexes of $P$. aibuhitensis and total nitrogen in the substrate under water-saturated wet-soil conditions were investigated to provide scientific guidance for the efficient and environmentally friendly farming of $P$. aibuhitensis.

\section{Materials and Methods}

No specific permit is required for operations on P. aibuhitensis in China.

\subsection{Specimen Collection}

In this study, large seedlings of the same batch of fertilized $P$. Aibuhitensis eggs were hatched at a salinity level of 21 according to the Specifications for Artificial Propagation of Perinereis aibuhitensis (Grube) (DB32/T2450-2013). The clamworms were dug from the soil carefully and cultivated in clean seawater with a salinity level of 21 to empty the intestine. About 2700 healthy individuals with an initial average mass of $20.4 \pm 0.3 \mathrm{mg}$ were selected and divided into nine groups (each group in triplicate). The salinity levels of the groups were adjusted (via three increments per day) to $9,12,15,18,21,24,27,30$, and 33 , respectively.

\subsection{Experimental Design and Feeding Management}

First, soil collected from a tidal flat in Sheyang county, Yancheng city, Jiangsu province in China, was washed with tap water repeatedly to remove salt, organic matter, and debris. Then, the soil was dried and sifted through a 10-mesh sieve and baked at $60^{\circ} \mathrm{C}$ for $8 \mathrm{~h}$. The soil was placed in polyethylene tanks (dimensions, $61 \mathrm{~cm} \times 41 \mathrm{~cm} \times 25 \mathrm{~cm}$ and sand depth, $10 \mathrm{~cm}$ ) and dipped in clean seawater with salinity levels of $9,12,15,18,21,24,27,30$, and 33. After the soil was soaked completely, the seawater was removed, and the water-saturated soil was obtained.

The $P$. aibuhitensis specimens were cultivated in the breeding tank at the corresponding salinity and fed at 08:00 and 19:00 every day; the daily feeding dose was $1 \%-2 \%$ and $2 \%-3 \%$ fresh weight of the clamworms, respectively. Table 1 indicates the formula and nutrients in the feed. After feeding, a suitable amount of fresh water was sprayed into the tank to supply moisture and soften the pellet fodder. The remaining bait was cleaned after feeding for $1.5-2 \mathrm{~h}$. During the rearing, the photoperiod in the room was 14 hours:10 hours (light: dark), and 
Table 1. Formulation of and ingredients in the experimental feed (\%, dry weight).

\begin{tabular}{cc}
\hline Ingredients & Percentage (\%) \\
\hline Fish meal & 20.00 \\
Soybean meal & 25.00 \\
Peanut meal & 18.00 \\
Fish oil & 6.00 \\
Corn starch & 29.00 \\
Choline chloride & 0.50 \\
Soy lecithin & 0.50 \\
Premix & 1.00 \\
Analytical composition & \\
Dry matter & 91.33 \\
Crude protein & 31.88 \\
Crude lipid & 8.41 \\
Ash & 7.59 \\
Carbohydrates & \\
Energy (kJ/g) & 33.45 \\
\hline
\end{tabular}

Note: ${ }^{1}$ Premix supplied the following minerals ( $\mathrm{g} / \mathrm{kg}$ ) and vitamins (IU or $\mathrm{mg} / \mathrm{kg}$ ): $13.5 \mathrm{~g} \mathrm{CuSO}{ }_{4} \cdot 5 \mathrm{H}_{2} \mathrm{O}, 58 \mathrm{~g}$ $\mathrm{FeSO}_{4} \cdot 7 \mathrm{H}_{2} \mathrm{O}, 65 \mathrm{~g} \mathrm{ZnSO}_{4} \cdot 7 \mathrm{H}_{2} \mathrm{O}, 16 \mathrm{~g} \mathrm{MnSO}_{4} \cdot 4 \mathrm{H}_{2} \mathrm{O}, 10.8 \mathrm{~g} \mathrm{Na}_{2} \mathrm{SeO}_{3} \cdot 5 \mathrm{H}_{2} \mathrm{O}, 12.64 \mathrm{~g} \mathrm{KI}, 21.5 \mathrm{~g} \mathrm{CoCl}_{2} \cdot 6 \mathrm{H}_{2} \mathrm{O}$, 1,600,000 IU VA, 500,000 IU VD 3 , $9000 \mathrm{mg} \mathrm{VE,} 450 \mathrm{mg} \mathrm{VK}$, $700 \mathrm{mg} \mathrm{VB}, 2500 \mathrm{mg} \mathrm{VB} 2,1000 \mathrm{mg} \mathrm{VB} 6,3.2$ $\mathrm{mg} \mathrm{VB} 12,18,000 \mathrm{mg} \mathrm{VC}, 2000 \mathrm{mg}$ pantothenate, $650 \mathrm{mg}$ folic acid, $1500 \mathrm{mg}$ niacin, $400 \mathrm{mg}$ biotin, $300 \mathrm{mg}$ myoinositol; ${ }^{2}$ Calculated by difference (dry matter - crude protein - crude lipid - ash) (Pedroetal., 2013); ${ }^{3}$ Computed as $21.3,17.2$, and $39.5 \mathrm{~kJ} / \mathrm{g}$ of proteins, carbohydrates, and lipids, respectively (Cuzonetal., 1997).

soil temperature in the breeding tank varied from $23^{\circ} \mathrm{C}$ to $26^{\circ} \mathrm{C}$. All the feeding experiments were conducted for 60 days at the Intertidal Organism Culture Laboratory in Yancheng Institute of Technology.

\subsection{Sample Collection and Indicators}

\subsubsection{Sample Collection and Growth Performance Calculation}

After the feeding trial, all the clamworms were fasted for $24 \mathrm{~h}$. Next, the clamworms were carefully removed from the breeding tanks and placed in clean seawater at an appropriate salinity level to empty the intestines. After the water on the surface of the clamworms was dried, the weight was recorded. Growth indicators, including the terminal average weight (TAW), survival rate (SR), specific growth ratio (SGR), feed conversion ratio (FCR) and protein efficiency ratio (PER) were calculated as described by Lv et al. [15] using the following equations.

$$
\begin{gathered}
S R(\%)=100 \times N_{f} / N_{i} \\
S G R(\% / d)=100 \times\left(\operatorname{Ln} W_{f}-\operatorname{Ln} W_{i}\right) / d \\
F C R=F /\left(W_{f}-W_{i}\right) \\
P E R=\left(W_{f}-W_{i}\right) /(F \times P)
\end{gathered}
$$


Among them, $N_{f}$ and $N_{i}$ indicate the number of clamworms after and before the experiment, respectively. $W_{f}$ and $W_{i}$ represent the weight (g) of the clamworms after and before the experiment, respectively; $d$ is the culture time (day); $F$ indicates the dry weight of food (g); and $P$ means the protein content of the food (\%).

\subsubsection{Measurement of Feed Nutrients and Body Content}

The proximate composition of each experimental diet and pooled whole clamworms from each treatment was analyzed based on AOAC methods [16]. The samples were dried at $105^{\circ} \mathrm{C}$ under standard pressure to calculate the water content. The content of crude protein was determined by measuring nitrogen $(\mathrm{N} \times 6.25)$ level using the Kjeldahl systematic method. The content of crude lipid was determined as described by Folch et al. [17]. Ash content was determined in a muffle furnace at $550^{\circ} \mathrm{C}$ for $8 \mathrm{~h}$. The determination of carbohydrate and total energy refers to Gómez-Requeni et al. [18] and Cuzon and Guillaume [19], respectively.

\subsubsection{Measurement of Antioxidant Indexes}

Five clamworms from each tank were removed randomly to measure the body weight and then mixed with $0.86 \%$ frozen saline to prepare the tissue homogenate. After centrifugation at $3000 \mathrm{rpm}$ and $4^{\circ} \mathrm{C}$ for $10 \mathrm{~min}$, the supernatant was used to measure the antioxidant indexes. SOD and CAT activities and reduced glutathione (GSH) and malondialdehyde (MDA) concentrations and the enzyme protein content were all measured using special kits provided by the Nanjing Jiancheng Bioengineering Institute (Nanjing, China).

\subsubsection{Measurement of Total Nitrogen in the Substrate}

From each tank, $100 \mathrm{~g}$ of mud was collected to measure the total nitrogen in the substrate before cultivation, according to Yuan's method [20]. After all the clamworms were removed, the soil in each tank was mixed thoroughly, and $100 \mathrm{~g}$ of soil from each tank was again collected to measure the total nitrogen in the substrate.

\subsection{Statistical Analysis}

The original data were edited by Excel 2007 and then analyzed using single-factor analysis of variance (one-way ANOVA; SPSS 17.0 software). If the difference was significant, Duncan's multiple comparison test was performed. Correlativity between the specific growth rate, feed conversion ratio, protein efficiency, and salinity levels were matched using the quadratic polynomial method. Data are presented as mean \pm standard deviation $(\mathrm{n}=3)$ values. $P<0.05$ was used to assess the statistical significance of the results.

\section{Results}

\subsection{Effects of Salinity on the Growth Performance and Feed Conversion of $P$, aibuhitensis}

Data in Table 2 indicate that the level of salinity has a certain influence on the 
Table 2. SR, SGR, FCR, DFI, and PER of Perinereis aibuhitensis at different salinity levels.

\begin{tabular}{ccccccc}
\hline Salinity & SR $(\%)$ & IAW $(\mathrm{mg} / \mathrm{EP})$ & TAW $(\mathrm{g} / \mathrm{EP})$ & SGR $\left(\%\right.$ day $\left.^{-1}\right)$ & FCR & PER \\
\hline 9 & $93.7 \pm 1.5^{\mathrm{a}}$ & $20.4 \pm 0.3$ & $251.4 \pm 15.2^{\mathrm{a}}$ & $4.08 \pm 0.16^{\mathrm{a}}$ & $1.82 \pm 0.13^{\mathrm{e}}$ & $1.73 \pm 0.12^{\mathrm{a}}$ \\
12 & $97.7 \pm 1.5^{\mathrm{b}}$ & $20.4 \pm 0.2$ & $313.1 \pm 13.5^{\mathrm{b}}$ & $4.51 \pm 0.07^{\mathrm{b}}$ & $1.42 \pm 0.03^{\mathrm{d}}$ & $2.21 \pm 0.05^{\mathrm{b}}$ \\
15 & $99.3 \pm 0.6^{\mathrm{b}}$ & $20.4 \pm 0.2$ & $356.2 \pm 25.6^{\mathrm{c}}$ & $4.75 \pm 0.11^{\mathrm{c}}$ & $1.22 \pm 0.07^{\mathrm{c}}$ & $2.57 \pm 0.15^{\mathrm{c}}$ \\
18 & $98.7 \pm 1.5^{\mathrm{b}}$ & $20.3 \pm 0.5$ & $373.4 \pm 16.8^{\mathrm{cd}}$ & $4.83 \pm 0.10^{\mathrm{cd}}$ & $1.15 \pm 0.03^{\mathrm{bc}}$ & $2.72 \pm 0.09^{\mathrm{cd}}$ \\
21 & $98.7 \pm 1.2^{\mathrm{b}}$ & $20.5 \pm 0.3$ & $413.9 \pm 13.1^{\mathrm{e}}$ & $4.99 \pm 0.08^{\mathrm{de}}$ & $1.05 \pm 0.03^{\mathrm{ab}}$ & $2.98 \pm 0.08^{\mathrm{ef}}$ \\
24 & $98.7 \pm 0.6^{\mathrm{b}}$ & $20.3 \pm 0.4$ & $430.7 \pm 14.6^{\mathrm{e}}$ & $5.07 \pm 0.06^{\mathrm{e}}$ & $1.02 \pm 0.01^{\mathrm{a}}$ & $3.08 \pm 0.04^{\mathrm{f}}$ \\
27 & $99.3 \pm 1.2^{\mathrm{b}}$ & $20.3 \pm 0.3$ & $409.9 \pm 24.5^{\mathrm{e}}$ & $4.99 \pm 0.11^{\mathrm{de}}$ & $1.07 \pm 0.04^{\mathrm{ab}}$ & $2.93 \pm 0.12^{\mathrm{ef}}$ \\
30 & $98.7 \pm 0.6^{\mathrm{b}}$ & $20.4 \pm 0.4$ & $407.2 \pm 24.9^{\mathrm{de}}$ & $4.97 \pm 0.09^{\mathrm{de}}$ & $1.08 \pm 0.02^{\mathrm{ab}}$ & $2.89 \pm 0.06^{\mathrm{e}}$ \\
33 & $98.7 \pm 1.2^{\mathrm{b}}$ & $20.4 \pm 0.2$ & $404.3 \pm 18.6^{\mathrm{de}}$ & $4.96 \pm 0.05^{\mathrm{de}}$ & $1.10 \pm 0.01^{\mathrm{ab}}$ & $2.84 \pm 0.02^{\mathrm{de}}$ \\
\hline
\end{tabular}

Note: Means represent mean $\pm \mathrm{SE}, \mathrm{n}=3$. Means in the same line with different superscripts are significantly different $(P<0.05)$. Terminal average weight, TAW; survival rate, SR; specific growth ratio, SGR; feed conversion ratio, FCR, protein efficiency ratio, PER; each Perinereis aibuhitensis, EP.

growth indexes of clamworms. The survival rate of clamworms at a salinity level of 9 was significantly lower than that of the other groups $(P<0.05)$. However, the survival rate of $P$. aibuhitensis at the other salinity levels was not significant $(P>0.05)$. As the salinity level increased, the specific growth rate and protein efficiency of $P$. aibuhitensis showed a downward trend after the first increase, while the changing trend of the feed conversion ratio was just the opposite. At higher salinity levels from 27 to 33 , the specific growth rate, feed conversion ratio, and protein efficiency of $P$. aibuhitensis were not significant $(P>0.05)$.

The efficiency relationship between salinity and specific growth rate, feed conversion ratio, and protein efficiency ratio was analyzed using the quadratic polynomial regression model. The regression equation for the relationship between specific growth rate and salinity is SGR $=-0.00319 \mathrm{~S}^{2}+0.16526 \mathrm{~S}+2.9228$ (see Figure 1). When $S=25.9$, specific growth rate was the highest. The regression equation for the relationship between feed conversion ratio and salinity is $F C R=0.00277 S^{2}-0.14047 \mathrm{~S}+0.7757$ (see Figure 2 ). When $\mathrm{S}=25.36$, feed conversion ratio was the lowest. The regression equation for the relationship between protein efficiency ratio and salinity is PER $=-0.00463 S^{2}+0.23665 S+$ 0.01339 (see Figure 3). When $S=25.56$, protein efficiency ratio was the highest. Thus, the optimal salinity range for $P$. aibuhitensis growth was $25.36-25.9$.

\subsection{Effect of Salinity on the Body Content of P. aibuhitensis}

Table 3 shows the different body compositions (moisture, crude protein, crude fat, and ash) of $P$. aibuhitensis due to different salinity levels. Overall, the body moisture content decreased with increasing salinity levels, but the difference in the salinity range of 15 to 33 was not significant $(P>0.05)$. Salinity had a significant influence on the crude protein content $(P<0.05)$, while it had no 


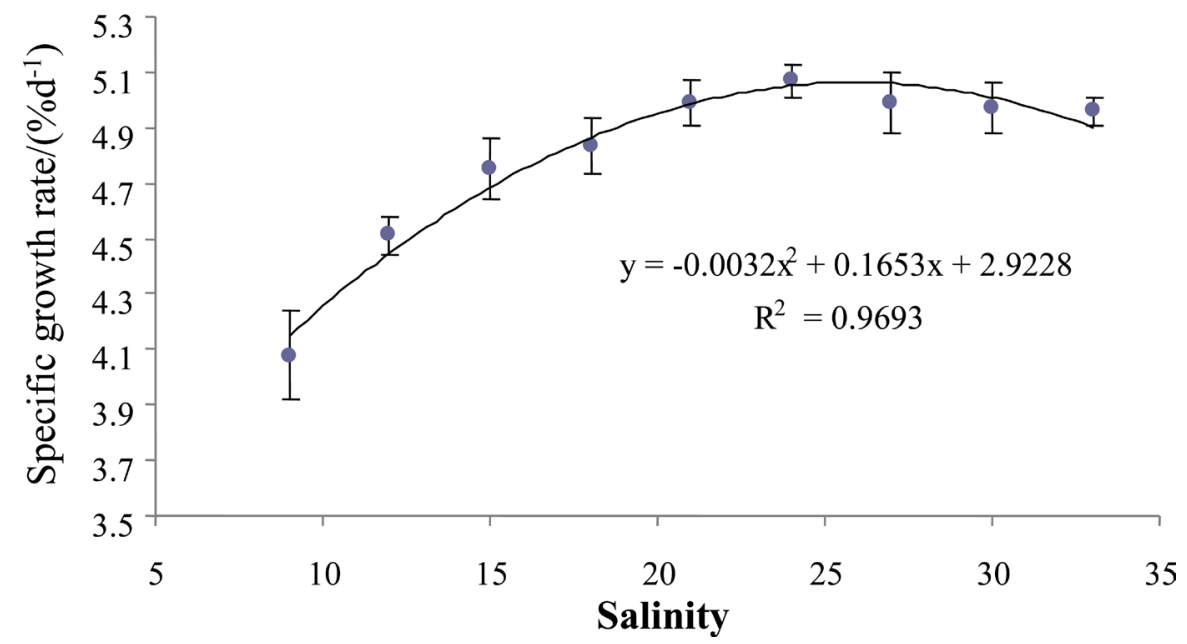

Figure 1. Regression equation for the relationship between specific growth rate (SGR) and salinity.

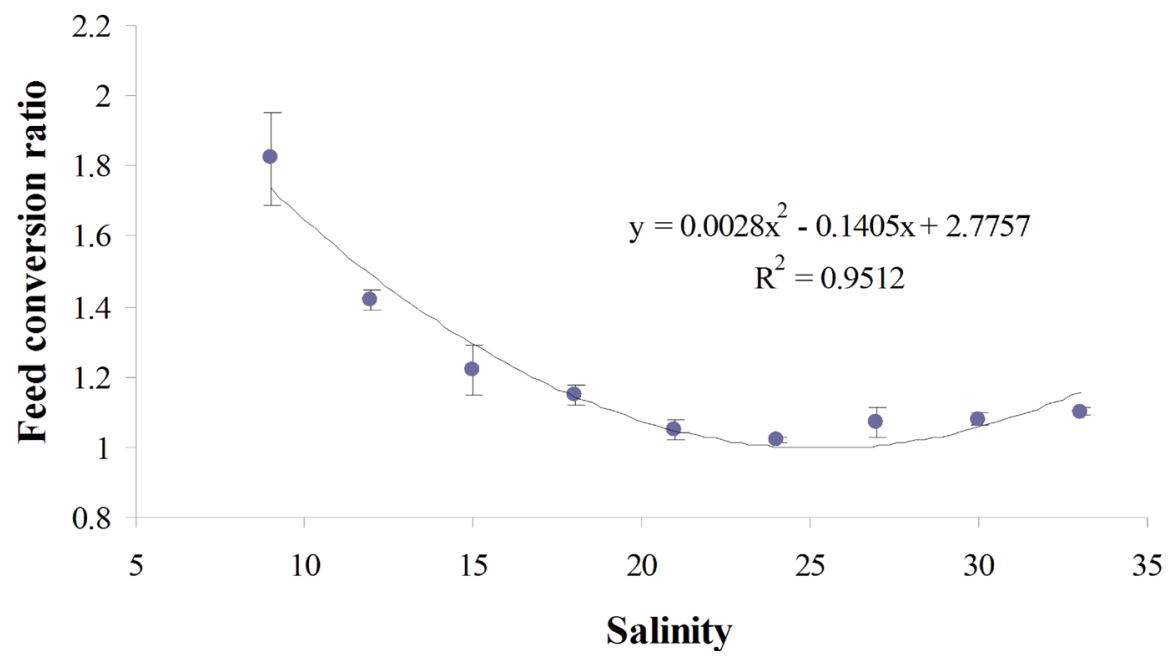

Figure 2. Regression equation for the relationship between feed conversion ratio (FCR) and salinity.

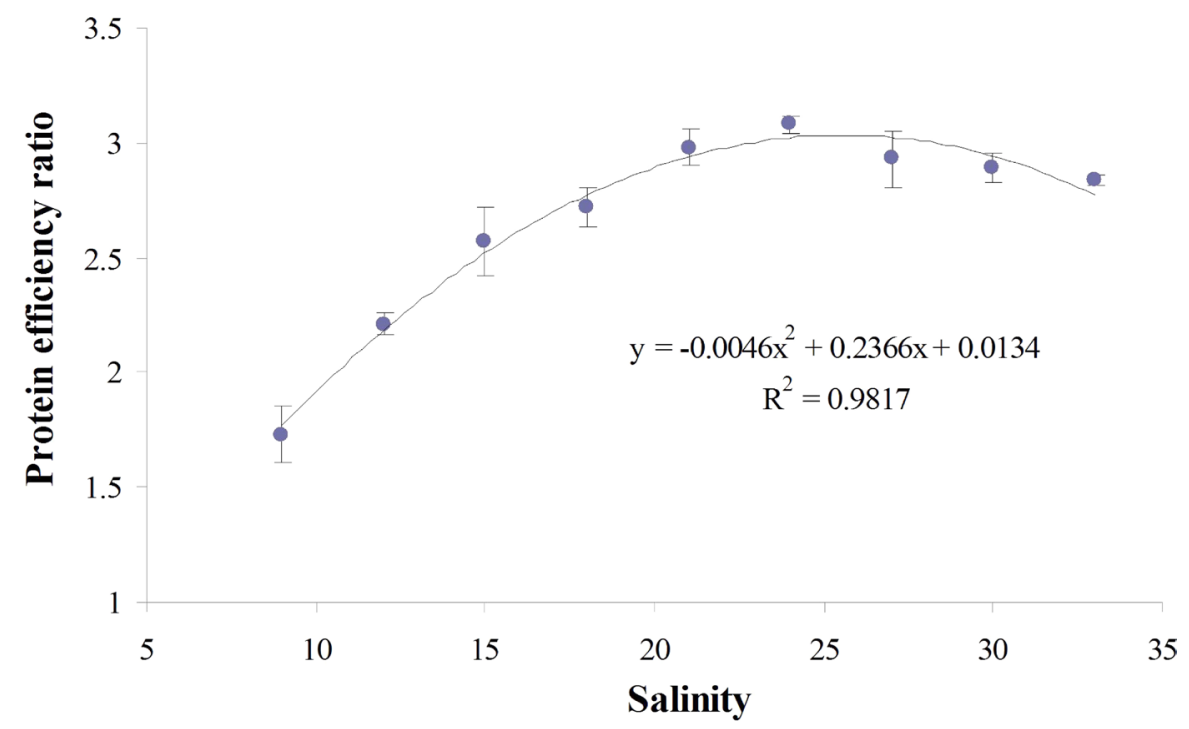

Figure 3. Regression equation for the relationship between protein efficiency ratio (PER) and salinity. 
Table 3. Body composition of Perinereis aibuhitensis at different salinity levels.

\begin{tabular}{ccccc}
\hline Salinity & Moisture (\%) & Crude protein (\%) & Crude lipid (\%) & Ash (\%) \\
\hline 9 & $83.11 \pm 0.48^{\mathrm{c}}$ & $52.76 \pm 0.64^{\mathrm{a}}$ & $8.06 \pm 0.44$ & $8.85 \pm 0.14^{\mathrm{a}}$ \\
12 & $82.93 \pm 0.62^{\mathrm{bc}}$ & $53.32 \pm 0.35^{\mathrm{ab}}$ & $8.13 \pm 0.19$ & $9.10 \pm 0.16^{\mathrm{ab}}$ \\
15 & $82.25 \pm 0.34^{\mathrm{ab}}$ & $54.30 \pm 0.11^{\mathrm{bc}}$ & $8.20 \pm 0.36$ & $9.23 \pm 0.16^{\mathrm{bc}}$ \\
18 & $82.24 \pm 0.18^{\mathrm{ab}}$ & $56.69 \pm 0.67^{\mathrm{d}}$ & $8.11 \pm 0.34$ & $9.39 \pm 0.13^{\mathrm{cd}}$ \\
21 & $82.26 \pm 0.40^{\mathrm{ab}}$ & $58.78 \pm 0.32^{\mathrm{e}}$ & $8.35 \pm 0.28$ & $9.48 \pm 0.18^{\mathrm{cd}}$ \\
24 & $82.16 \pm 0.60^{\mathrm{ab}}$ & $59.02 \pm 0.36^{\mathrm{e}}$ & $8.30 \pm 0.12$ & $9.57 \pm 0.12^{\mathrm{d}}$ \\
27 & $82.11 \pm 0.49^{\mathrm{ab}}$ & $57.09 \pm 0.53^{\mathrm{d}}$ & $8.29 \pm 0.31$ & $9.60 \pm 0.14^{\mathrm{d}}$ \\
30 & $81.66 \pm 0.46^{\mathrm{a}}$ & $54.92 \pm 0.80^{\mathrm{c}}$ & $8.17 \pm 0.32$ & $9.56 \pm 0.11^{\mathrm{d}}$ \\
33 & $81.40 \pm 0.54^{\mathrm{a}}$ & $54.70 \pm 0.98^{\mathrm{c}}$ & $8.35 \pm 0.37$ & $9.57 \pm 0.21^{\mathrm{d}}$ \\
\hline
\end{tabular}

Note: Means represent mean $\pm \mathrm{SE}, \mathrm{n}=3$. Means in the same line with different superscripts are significantly different $(P<0.05)$.

significant influence on crude body fat. Crude protein showed an increasing trend with the salinity increasing from 9 to 24, and decreased with the salinity increasing from 24 to 33 . The ash content was relatively low when the salinity level was low. As the salinity level increased, the ash content increased gradually. However, in the salinity range of 18 to 33 , the difference in ash content was not significant $(P>0.05)$.

\subsection{Effects of Salinity on the Antioxidant Indexes of $P$. aibuhitensis}

Table 4 shows the main antioxidant enzyme levels (SOD and CAT) and amounts of two non-enzymatic antioxidant small molecules (GSH and MDA) under different salinity levels. The MDA content was significantly higher in the clamworms under low salinity levels of 9 to 18 than in those under salinity levels of 21 to $33(P<0.05)$. However, the MDA content was generally low and showed no obvious differences $(P>0.05)$ in the salinity range of 21 to 33 . SOD and CAT activities showed a declining and rising trend when the salinity level increased gradually; the lowest SOD value was observed at the salinity level of 24 , and the lowest CAT value, at 21 .

\subsection{Effects of Salinity on Total Nitrogen in the Substrate}

Table 5 shows the total nitrogen content in the soil in which the P. aibuhitensis specimens were reared for 60 days under different salinity levels. Compared to the original value of TNC $(0.215 \pm 0.009 \mathrm{~g} / \mathrm{kg})$, the total nitrogen content of each group was obviously increased. Overall, the total nitrogen content first declined and then increased, and the lowest value was observed at the salinity level of 24 . The total nitrogen content showed no significant differences $(P>0.05)$ in the salinity range of 21 to 27 . 
Table 4. Antioxidant indexes of Perinereis aibuhitensis at different salinity levels.

\begin{tabular}{ccccc}
\hline Salinity & SOD (U/mgprot) & CAT (U/mgprot) & GSH (nmol/mgprot) & MDA (nmol/mgprot) \\
\hline 9 & $25.49 \pm 2.09^{\mathrm{e}}$ & $15.80 \pm 0.31^{\mathrm{e}}$ & $7.11 \pm 0.41$ & $6.87 \pm 0.23^{\mathrm{e}}$ \\
12 & $23.13 \pm 0.89^{\mathrm{d}}$ & $14.28 \pm 0.22^{\mathrm{d}}$ & $6.77 \pm 0.82$ & $6.46 \pm 0.11^{\mathrm{d}}$ \\
15 & $19.92 \pm 0.71^{\mathrm{c}}$ & $13.79 \pm 0.34^{\mathrm{d}}$ & $6.18 \pm 0.57$ & $4.50 \pm 0.38^{\mathrm{c}}$ \\
18 & $18.97 \pm 0.52^{\mathrm{bc}}$ & $12.81 \pm 0.85^{\mathrm{bc}}$ & $6.19 \pm 0.23$ & $3.61 \pm 0.18^{\mathrm{b}}$ \\
21 & $17.84 \pm 0.99^{\mathrm{bc}}$ & $11.35 \pm 0.78^{\mathrm{a}}$ & $6.16 \pm 0.20$ & $2.83 \pm 0.14^{\mathrm{a}}$ \\
24 & $15.59 \pm 0.78^{\mathrm{a}}$ & $11.52 \pm 0.75^{\mathrm{a}}$ & $6.24 \pm 0.28$ & $2.57 \pm 0.11^{\mathrm{a}}$ \\
27 & $17.12 \pm 1.04^{\mathrm{ab}}$ & $12.11 \pm 0.36^{\mathrm{ab}}$ & $6.20 \pm 0.25$ & $2.65 \pm 0.09^{\mathrm{a}}$ \\
30 & $17.36 \pm 1.13^{\mathrm{ab}}$ & $12.24 \pm 0.53^{\mathrm{ab}}$ & $6.51 \pm 0.86$ & $2.67 \pm 0.14^{\mathrm{a}}$ \\
33 & $18.49 \pm 1.30^{\mathrm{bc}}$ & $12.61 \pm 0.39^{\mathrm{bc}}$ & $6.42 \pm 0.24$ & $2.73 \pm 0.12^{\mathrm{a}}$ \\
\hline
\end{tabular}

Note: Means represent mean $\pm \mathrm{SE}, \mathrm{n}=3$. Means in the same line with different superscripts are significantly different $(P<0.05)$.

Table 5. Total nitrogen content in the soil in which Perinereis aibuhitensis specimens were reared at different salinity levels.

\begin{tabular}{cc}
\hline Salinity & Total nitrogen $(\mathrm{g} / \mathrm{kg})$ \\
\hline 9 & $1.646 \pm 0.042^{\mathrm{f}}$ \\
12 & $1.264 \pm 0.037^{\mathrm{e}}$ \\
15 & $0.958 \pm 0.020^{\mathrm{d}}$ \\
18 & $0.737 \pm 0.023^{\mathrm{c}}$ \\
21 & $0.508 \pm 0.018^{\mathrm{a}}$ \\
24 & $0.495 \pm 0.013^{\mathrm{a}}$ \\
27 & $0.527 \pm 0.017^{\mathrm{a}}$ \\
30 & $0.635 \pm 0.016^{\mathrm{b}}$ \\
33 & $0.653 \pm 0.025^{\mathrm{b}}$
\end{tabular}

Note: Means represent mean $\pm \mathrm{SE}, \mathrm{n}=3$. Means in the same line with different superscripts are significantly different $(P<0.05)$.

\section{Discussion}

A previous study has shown that the salinity levels suitable for the growth of $P$. aibuhitensis have a broad range [13]. In this study, the salinity levels were observed to affect the growth performance, body composition, and antioxidant indexes of $P$. aibuhitensis and total nitrogen in substrate.

\subsection{Effects of Salinity on the Growth Performance of $P$. aibuhitensis}

The survival rate of $P$. aibuhitensis at the salinity level of 9 was significantly lower than that of $P$. aibuhitensis in the other groups $(P<0.05)$; this is similar to the results obtained by Zhu et al. [21]. The main reason may be that the low-salinity environment exceeded the ability of $P$. aibuhitensis to regulate the osmotic pressure, resulting in the instability of the internal environment of the clam- 
worms and metabolic disorders. Thus, some clamworms with a poor ability to adjust the osmotic pressure began to appear abnormal, and even died. Only clamworms with a strong adjustment ability can gradually adapt to a low-salinity environment. The growth performance indexes SGR and PER were significantly lower at low salinity levels of 9 to 12 than at high salinity levels, while FCR was significantly higher at low salinity levels of 9 to 12 than at high salinity levels ( $P$ $<0.05)$. The main reason is that low salinity has an adverse effect on feed conversion, oxygen consumption rate, metabolism, digestive enzyme activities, and immunity of aquatic animals [22] [23]. At the same time, osmoregulation and other related physiological functions need additional energy, resulting in low SGR and PER and high FCR and finally causing a decline in the growth performance [24].

The quadratic polynomial regression model was used to analyze the efficiency relationship between salinity and specific growth rate, feed conversion ratio, and protein efficiency ratio of $P$. aibuhitensis, and the appropriate salinity range for the growth performance of $P$. aibuhitensis was observed to vary from 25.36 to 25.9. Within this range of salinity, the clamworms showed the highest specific growth rate and protein efficiency, lowest feed coefficient, and relatively high growth indicators. According to the principle of isotonic adjustment, aquatic animals such as euryhaline fish show the lowest penetration pressure, lowest metabolic rate, and highest rate of growth at the isotonic point [25]. When the salinity level is varied from 25.36 to 25.9 , environmental salinity may be closer to the isotonic point of the clamworms, and they show a good growth trend. If the clamworms are cultivated at a lower or higher salinity environment in which the salinity level deviates greatly from the isotonic point, the clamworms have to use a lot of energy to regulate the osmotic pressure and maintain a stable internal environment; thus, the energy used for metabolism, growth, and other life activities is reduced [26]. Thus, low or high salinity will inhibit the growth of $P$. aibuhitensis. However, $P$. aibuhitensis showed better growth at high salinity than at low salinity.

\subsection{Effects of Salinity on the Body Content of $P$, aibuhitensis}

The body moisture content of $P$. aibuhitensis decreased with increasing salinity level and was significantly higher at low salinity levels than at high salinity levels $(P<0.05)$, which is consistent with the Penaeus vannamei [27]. The main reason is that clamworms in a low-salt environment need to absorb more water to maintain homeostasis and enhance their ability to adapt to the environment.

Maximum crude protein contents were observed at the salinity level of 24 . The energy clamworms use to perform osmotic regulation is mainly provided by the body lipids and proteins, so salinity can also affect the behavior, feeding, and immunity of clamworms [26]. Thus, the combined effects of salinity on the physiological functions of clamworms determine changes in their body fat and protein contents [24]. When the salinity level is around 24, body fluid of P. aibuhi- 
tensis may be very close to the water osmotic pressure, which means that less the energy required for regulating osmotic pressure, less the consumption of proteins and fat. As a result, the body fat and crude protein contents are higher. At higher salinity levels of about 24 to 33 , the body ash content was at a high level, and the difference was not significant $(P>0.05)$.

\subsection{Effects of Salinity on the Antioxidant Indexes of $P$, aibuhitensis}

An excess of reactive oxygen species (ROS), such as hydrogen peroxide $\left(\mathrm{H}_{2} \mathrm{O}_{2}\right)$, not only kill invasion pathogens but also damage the body itself, such as converting unsaturated fatty acids, destroying the cell membrane structure, and causing DNA degradation [28]. MDA is a hazardous peroxide produced by peroxidation, and its content indicates the degree of oxidation. Antioxidant enzyme systems of aquatic animals (mainly SOD and CAT) play an important role in removing excess free radicals and alleviating body damage [29]. Thus, the antioxidant enzyme system is an important immune response system for aquatic animals to deal with salinity and other environmental stresses [30].

Peroxidation can not only lead to elevated levels of MDA but also induce increased SOD and CAT activities and GSH content to clear the free radicals produced by peroxidation. Therefore, the level of antioxidant enzyme activity can reflect the physiological condition of $P$. aibuhitensis at different salinity levels to some extent, and it can be used as an important physiological indicator for measuring whether aquatic animals are stressed by salinity [31]. In this study, the $P$. aibuhitensis specimens were found to have high MDA content and SOD and CAT activities at low salinity. The main reason for this phenomenon may be because $P$. aibuhitensis experiences body stress, resulting in an increased metabolic rate, oxygen consumption rate, and demand for energy. The short-term increase in the contents of MDA and other antioxidant small molecules induces an increase in antioxidant enzyme activity, which helps to increase the resistance of $P$. aibuhitensis to the external environment; this was confirmed by a study on Takifugu obscurus conducted by Bian et al. [32]. In the salinity range of 21 to 33, MDA level in $P$. aibuhitensis is low and shows no differences with changes in salinity $(P>0.05)$. Considering the abovementioned growth indicators of $P$. aibuhitensis, it might be that in an appropriate salinity range, $P$. aibuhitensis shows a good growth trend and low active oxygen content. The antioxidant enzyme system can effectively remove free radicals and ROS from the body, meaning that free radical production and clearance are in dynamic equilibrium [29].

\subsection{Effects of Salinity on Total Nitrogen in the Substrate}

Total nitrogen in the substrate refers to the sum of organic and inorganic nitrogen, such as $\mathrm{NO}_{3}^{-}, \mathrm{NO}_{2}^{-}, \mathrm{NH}_{4}^{+}$, and $\mathrm{NH}_{3}$, in the substrate. In this experiment, total nitrogen content of the sediment in which the clamworms were reared for 60 days was much higher than the soil total nitrogen.

At salinity in the range of 9 to 33 , the total nitrogen content of the sediment 
decreased first as the salinity increased and then reached a minimum value when the salinity was around 24. Finally, it increased with increasing salinity levels. The following two points were speculated after the experiment, but further studies are required to prove them. 1) The total nitrogen content may be affected by the ammonia excretion rate of the clamworms. A previous study showed that salinity has an effect on the ammonia excretion rate [33]. In this experiment, the total nitrogen content increased at first and then decreased with an increase of salinity, and the lowest values were observed at the salinity level of 24. Salinity of about 24 may be more appropriate for the growth and survival of $P$. aibuhitensis with less direct elimination of ammonia produced by protein metabolism, resulting in the low ammonia excretion rate. Therefore, the total nitrogen content in the substrate was low. 2) The total nitrogen content of the substrate may be related to the digestive enzyme activities of the clamworms. Digestion and absorption of nutrition require the digestive enzymes of aquatic animals. Since the amount of ions may change when they are accumulated in the digestive glands of aquatic animals under different salinity conditions, the activities of digestive enzymes may be different; other mechanisms may also exist, for example, a change in salinity at a certain range may affect the endocrine physiology of aquatic animals, thereby affecting the secretion of digestive enzymes and dynamic changes [34]. This can be divided into activating effect, no effect, and inhibition [35]. P. aibuhitensis showed relatively better growth performance at the salinity of about 24 . With the activating effect of salinity on the enzymatic activity of clamworms, the activities of the digestive enzymes, such as proteases, are increased, which means the higher apparent digestibility of clamworms, and lower organic nitrogen content in the feces.

\section{Acknowledgements}

We thank the ELIXIGEN (Shanghai, China) Co., Ltd. for the language editing service. This study was supported by grants from the National Spark Program project (2014GA690027), the Jiangsu Agricultural Science and Technology Support Program Project (BE2014346), the Yancheng agricultural science and technology innovation special guidance funds (YK2016029), and the Opening Project of Jiangsu Key Laboratory of Biochemistry and Biotechnology of Marine Wetland (K2016013).

\section{References}

[1] Ye, F.L. (2002) Fish Ecology. Guangdong Higher Education Press, Guangzhou, 22-84.

[2] You, H.Z., Sun, Z.J. and Zhang, Q. (2013) Effects of Salinity on Feeding, Growth and Body Composition of Juvenile Leopard Coral Trout Plectropomus leopardus. Journal of Dalian Ocean University, 28, 89-93.

[3] Zhang, G.Z., Huang, G.Q. and Tian, S.J. (2008) Effect of Salinity Stress and Following Recovery on the Growth, Energy Allocation and Body Composition of Juvenile Paralichthys olivaceus. Journal of Fisheries of China, 32, 402-410. 
[4] You, H.Z., Yang, Z.Q. and Ge, S.S. (2009) Effects of Salinity on Muscle Biochemical Composition and Energy Budget of Juvenile Platichthys stellatus. Hebei Fisheries, 1, 16-19.

[5] Liu, X.M., Li, X.X. and Leng, X.J. (2008) Comparative Study of Salinity on Growth and Muscle Composition of Tilapia and Snakehead. Journal of Shanghai Fisheries University, 17, 242-246.

[6] Wang, X.J., Zhang, X.M. and Li, W.T. (2005) Effects of Salinity on the Non-Specific Immuno-Enzymetic Activity of Sebastes schlegeli. Marine Fisheries Research, 26, 137-142.

[7] Wang, Y.B., Hu, Z.H. and Zhu, Y.H. (2015) Effect of Salinity on Growth and Non-Specific Immunity of Nibea japonica. Journal of Zhejiang Ocean University, 34, 26-31.

[8] Sun, R. and Yang, D.J. (2004) Fauna Sinica, Invertebrate. Annelida, Polychaeta (II), Nereidida, 33, 30-41

[9] Deng, J.S., Ma, S., Niu, H.X., Dong, S.L. and Su, Y.P. (2007) An Experiment of Shrimp (Fenneropenaeus chinensis) Culture by Inputting Polychaetes (Perinereis aibuhitensis). Transactions of Oceanology and Limnology, 2, 135-140.

[10] Liu, S.L., Liu, Y., Yang, H.S., You, K., Chen, M.Y. and Yu, L.D. (2006) Effects of Perinereis aibuhitensis and Eisenia foetida on Growth and Immune Parameters of the Shrimp Litopenaeus vannamei. Journal of Fishery Sciences of China, 13, 561-565.

[11] Gu, X.Y., Jiang, X.M., Zheng, Z.M. and Jin, C.H. (2002) Biological Characteristics of Perinereis aibuhitensis Grube and Status of Its Utilization. Modern Fisheries Information, 17, 33-34.

[12] Pan, W., Liu, X., Ge, F., Han, J. and Zheng, T. (2004) Perinerin, a Novel Antimicrobial Peptide Purified from the Clamworm Perinereis aibuhitensis Grube and Its Partial Characterization. Journal Biochemistry (Tokyo), 135, 297-304. https://doi.org/10.1093/jb/mvh036

[13] Feng, S.C., Huang, G.Q. and Lai, Z.P. (2014) Tolerability Study of Temperature, Salinity and Exposure and Desiccation of Perinereis aibuhitensis. Transactions of Oceanology and Limnology, 1, 109-114.

[14] Li, X.S., Peng, Y.X. and Shao, Y.Z. (2006) Impact of Salinity and Body Weight on Growth of Perinereis aibuhitensis. Reservoir Fisheries, 26, 14-15.

[15] Lv, F., Liu, F., Yu, Y., Wang, A., Yang, W., Nie, Q. and Wang, T. (2017) Effects of Dietary Lipid Levels on Growth, Body Composition and Antioxidants of Clamworm (Perinereis aibuhitensis). Aquaculture Reports, 6, 1-7. https://doi.org/10.1016/j.aqrep.2017.02.001

[16] Horowitz, W. and Latimer, G.W. (2006) Official Methods of Analysis of AOAC International. 18th Edition, Gaithersburg Md.

[17] Folch, J., Lees, M. and Sloane-Stanley, G. (1957) A Simple Method for the Isolation and Purification of Total Lipids from Animal Tissues. Journal of Biological Chemistry, 226, 497-509.

[18] Gómez-Requeni, P., Bedolla-Cázares, F., Montecchia, C., Zorrilla, J., Villian, M., Toledo-Cuevas, E.M. and Canosa, F. (2013) Effects of Increasing the Dietary Lipid Levels on the Growth Performance, Body Composition and Digestive Enzyme Activities of the Teleost Pejerrey (Odontesthes bonariensis). Aquaculture, 416, 15-22. https://doi.org/10.1016/j.aquaculture.2013.08.027

[19] Cuzon, G. and Guillaume, J. (1997) Energy and Protein: Energy Ratio. In: D’Abramo, L.R., Conklin, D.E. and Akiyama, D.M., Eds., Crustacean Nutrition, Advances in World Aquaculture Vol. VI, World Aquaculture Society, USA, 51-70. 
[20] Yuan, J., Ji, P.Y. and Yuan, Y. (2009) Measurement of Total Nitrogen in the Soil with Amended Kjeldahl Determination. Environmental Science and Management, 34, 143-146.

[21] Zhu, F.X., Wang, J.Y. and Tao, S.S. (1999) Holding Technology Research of Perinereis aibuhitensis. Qilu Fisheries, 16, 1-2.

[22] Bowden, T.J. (2008) Modulation of the Immune System of Fish by Their Environment. Fish \& Shellfish Immunology, 25, 373-383.

https://doi.org/10.1016/j.fsi.2008.03.017

[23] Tsuzuki, M.Y., Sugai, J.K., Maciel, J.C., Francisco, C.J. and Cerqueira, V.R. (2007) Survival, Growth and Digestive Enzyme Activity of Juveniles of the Fat Snook (Centropomus parallelus) Reared at Different Salinities. Aquaculture, 271, 319-325. https://doi.org/10.1016/j.aquaculture.2007.05.002

[24] Zeng, L., Lei, J.L. and Liu, B. (2013) Effects of Salinity on Growth and Muscle Composition of Juvenile Turbot Scophthalmus maximus. Journal of Fisheries of China, 37, 1535-1541. https://doi.org/10.3724/SP.J.1231.2013.38714

[25] Kilambi, R.V. (1980) Food Consumption, Growth and Survival of Grass Carp Ctenopharyngodon idella Val at Four Salinities. Journal of Fish Biology, 17, 613- 618. https://doi.org/10.1111/j.1095-8649.1980.tb02794.x

[26] Boeuf, G. and Payan, P. (2001) How Should Salinity Influence Fish Growth? Comparative Biochemistry and Physiology-Part C: Toxicology \& Pharmacology, 130, 411-423. https://doi.org/10.1016/S1532-0456(01)00268-X

[27] Huang, K., Wang, W. and Lu, J. (2004) Effects of Salinity on Growth and Biochemical Composition of Penaeus vannamei. Marine Science, 28, 20-25.

[28] Xing, J., Lin, T.T. and Zhan, W.B. (2008) Variations of Enzyme Activities in the Haemocytes of Scallop Chlamys farreri after Infection with the Acute Virus Necrobiotic Virus (AVNV). Fish \& Shellfish Immunology, 25, 847-852. https://doi.org/10.1016/j.fsi.2008.09.008

[29] Pipe, R.K., Porter, C. and Livingstone, D.R. (1993) Antioxidant Enzymes Associated with the Blood Cells and Hemolymph of the Mussel Mytilus edulis. Fish \& Shellfish Immunology, 3, 221-233. https://doi.org/10.1006/fsim.1993.1022

[30] Li, Z.N., Lin, T.T. and Yao, Z.L. (2012) Effect of Salinity on Antioxidant Enzyme Activity and Growth of Clam Cyclina sinensis. Chinese Journal of Ecology, 31, 2625-2630.

[31] Wang, Y., Zhuang, P. and Zhang, L.Z. (2011) Effects of Salinity on Survival, Growth and Antioxidant Defense System of Siganus guttatus. Journal of Fisheries of China, 35, 66-73.

[32] Bian, P.J., Qiu, C.G. and Xu, S.L. (2014) Effect of Salinity on Growth, Non-Specific Immunity and Antioxidant Enzyme Activity of Takifugu obscurus. Acta Hydrobiologica Sinica, 38, 108-114.

[33] Cai, D.Y. and Yan, X.Z. (2014) Effects of Salinity on Oxygen Consumption Rate and Ammonia-N Excretion Rate of Perinereis aibuhitensis. Marine Sciences, 38, 54-57.

[34] Lv, F., Huang, J.T. and Yu, Y.B. (2010) Effects of Salinity on Growth, Muscle Composition and Protease Activity of Portunus trituberculatus. Transactions of Oceanology and Limnology, 4, 137-142.

[35] Luo, M.Z., Guan, R.Z. and Lin, H. (2015) Effects of Salinity on Growth Performance and Digestive Enzyme Activity of Flower Eel and Pacific Double-Color Eel Elver. Acta Hydro biologica Sinica, 39, 653-660. 